\title{
Dewatering, Stabilization, and Final Disposal of Waste Activated Sludge in Constructed Wetlands
}

Deshidratación, estabilización y disposición final de descarte de lodos activados en humedales construidos

Submitted on: May 14, 2019 | Accepted on: June 4, 2020 | Published: June 17, 2021

\author{
Alejandro J. Mariñelarena ${ }^{\text {a }}$ \\ ILPLA, UNLP, FCNyM, Argentina \\ ORCID: 0000-0001-8202-8354 \\ Hugo D. Di Giorgi \\ ILPLA, CIC, Argentina \\ ORCID: 0000-0003-0826-7634 \\ Jorge L. Donadelli \\ ILPLA, Conicet, Argentina \\ ORCID: 0000-0003-2688-0547
}

${ }^{a}$ Corresponding author. E-mail: alemar@ilpla.edu.ar

DOI: https://doi.org/10.11144/Javeriana.iued25.dsfd

How to cite this article:

A. J. Mariñelarena, H. D. Di Giorgi, and J. L. Donadelli, "Dewatering, stabilization, and final disposal of waste activated sludge in constructed wetlands," Ing. Univ., vol. 25, 2021 [Online]. https://doi.org/10.11144/Javeriana.ived25.dsfd 


\section{Abstract}

Objective: This research aimed to assay the dehydration and stabilization of surplus biosolids from a wastewater activated sludge treatment plant, with sludge-treatment wetlands, at the Iguazú National Park (Misiones, Argentina). Materials and Methods: A 12-cell sludge-treatment reed beds (STRB) system was built and operated for four years. Afterwards, the accumulated sediments were analyzed for total solids (TS) concentration, volatile solids (VS) reduction, specific oxygen-uptake rate (SOUR), and heavy metals and pathogens concentrations. Results and Discussion: TS concentration increased from $0.55 \%$ to $14.3 \%$, VS were reduced by $33.3 \%$, and SOUR lowered to $1.09 \mathrm{mg} \mathrm{O}_{2} \mathrm{gTS}^{-1} \mathrm{~h}^{-1}$. These figures and the final concentrations of heavy metals and pathogenic microorganisms (102 MPN E.coli.gTS ${ }^{-1}$ ) indicated a degree of stabilization and sanitation that allowed classifying these biosolids as Class A, according to the Argentine guidelines, National Resolution 410/18, and enabled their reuse for soil amendment in landscapes and other agronomic purposes. Conclusion: The technology tested showed good results applied under a tropical climate, with annual temperatures between 17 and $27{ }^{\circ} \mathrm{C}$, rainfall of $1870 \mathrm{~mm} \mathrm{y}^{-1}$, and planted with autochthonous vegetation. Furthermore, it allowed the reuse of $221 \mathrm{t}\left(144 \mathrm{~m}^{3}\right)$ of a harmless product in an environmentally sustainable way.

Keywords: vegetated beds, dehydration, sludge treatment, stabilization, treatment wetlands.

\section{Resumen}

Objetivo: esta investigación tuvo como objetivo analizar la deshidratación y estabilización de biosólidos excedentes de una planta de tratamiento de lodos activados mediante humedales construidos, en el Parque Nacional Iguazú (Misiones, Argentina). Materiales $y$ métodos: se construyó un sistema de lechos vegetados para tratamiento de lodos de 12 celdas y se operó durante cuatro años. Posteriormente, los sedimentos acumulados se analizaron para determinar la concentración de sólidos totales (ST), la reducción de sólidos volátiles (SV), la tasa específica de absorción de oxígeno (SOUR) y las concentraciones de metales pesados y patógenos. Resultados y discusión: la concentración de ST aumentó de $0,55 \%$ a $14,3 \%$, la de SV se redujo un $33,3 \%$ y la SOUR a $1,09 \mathrm{mg}$ de $\mathrm{O}_{2} \mathrm{gTS}^{-1} \mathrm{~h}^{-1}$. Estas cifras y las concentraciones finales de metales pesados y microorganismos patógenos (102 MPN E.coli.gTS ${ }^{-1}$ ) indicaron un grado de estabilización y saneamiento que permitió clasificar esos biosólidos como clase A, que, de acuerdo con las directrices argentinas Resolución nacional 410/18, habilita su reutilización para la enmienda de suelos en usos paisajísticos y otros fines agronómicos. Conclusión: la tecnología utilizada mostró buenos resultados bajo un clima tropical, con temperaturas anuales entre 17 y $27{ }^{\circ} \mathrm{C}$, precipitaciones de $1870 \mathrm{~mm} \mathrm{y}^{-1}$ y plantadas con vegetación autóctona. Además, permitió la reutilización de $221 \mathrm{t}\left(144 \mathrm{~m}^{3}\right)$ de un producto inofensivo de una manera ambientalmente sostenible.

Palabras clave: lechos vegetados, deshidratación, tratamiento de lodos, estabilización, humedales de tratamiento. 


\section{Introduction}

Biological wastewater treatment systems, especially those using a suspended biomass like activated sludge, generate a surplus of microbial biomass (sludge, biosolids) that must be systematically discarded in order to ensure the stability of the treatment process and the quality of the final effluent. These residues need further treatment and a disposal that involves the dehydration of the mud, the reduction of the organic load, removal of pathogens, and the control of heavy-metal concentrations - procedures that represent a problem worldwide.

A technology designed for the treatment of waste biosolids in constructed wetlands referred to as the sludge treatment in reed beds, STRB by Nielsen and Bruun [1], the planted drying beds, PDB by Kengne and Tilley [2], and the sludge-treatment wetlands, STW by Uggetti et al. [3] - has proven to be a suitable alternative to the dehydration and stabilization of surplus sludge both environmentally and economically. These systems are made up of 8 to 12 cells with a filtering floor that is planted with helophytes. Every day, waste sludge is poured into each cell. The water content filters through the floor and is thus returned to the reactor, while the solid wastes are retained on the surface. The physiology of the plants favors further sludge dehydration through water absorption and transpiration. The microbial activity within the root environment (rhizosphere) digests and stabilizes the organic fraction of the sludge. When the capacity of the cells is reached (after 5 to 10 years), the accumulated residue is removed, and the filtering surface is recomposed and replanted. The cells then become operable again. If the treated residue meets certain quality standards, that material can be used as fertilizer or for soil amendments or other defined agronomic purposes.

The Iguazú National Park (INP, Misiones, Argentina, 25 40' 40" S, 54 26' 42" W), has a secondary-level treatment plant (activated sludge) to treat the wastewater generated in the sanitary and gastronomic services of the park. In 2012, a 12-cell wetland system was designed for the treatment of surplus biosolids, utilizing the filtering floor and drainage from the existing sludge-drying beds. After four years of operation, the sediments were sampled and analyzed as required by the National Resolution 410/18 [4], to classify the treated biosolids and to define their possible utilization or final disposal destination.

This is our first experience in the application of this technology in Argentina. The aim of the project was first to analyze the performance of the wetland system under local climatic conditions and with native vegetation, and then to evaluate if the sludge so treated met the requirements of the current regulations for further use for agronomic purposes. 


\section{Materials and Methods}

\section{Experimental Set-Up}

Climate. The Iguazú climate is defined as humid subtropical, with an average medium temperature of $22{ }^{\circ} \mathrm{C}$ (range 17 to $27^{\circ} \mathrm{C}$ ) and an average rainfall of $1,870 \mathrm{~mm} \mathrm{yr}^{-1}$ (monthly average $156 \mathrm{~mm}$; range 94 to $226 \mathrm{~mm}$ ).

Cell system. Two existing sludge drying beds (18 x $7.25 \mathrm{~m}, 130.5 \mathrm{~m}^{2}$ each), divided by masonry walls into 12 cells $\left(2.80 \times 7.25 \mathrm{~m}, 20.3 \mathrm{~m}^{2}\right)$, and numbered from 1 to 12 were employed. (figure 1). The upper brick layer of the cells' floor was removed and replaced with a $15-\mathrm{cm}$ layer of sand for the planting. The dividing walls extended 0.7 to $0.8 \mathrm{~m}$ above the sand. On top of the walls, a network of pipes and valves allowed the direct delivery of the sludge to the selected cells.

Figure 1. Schema of the 12-cell sludge-treatment reed bed (wetlands). Solid lines: Walls of preexisting drying beds; dashed lines: New traverse walls dividing cells; double dashed lines: Drainage pipes under the floor. Below: Different layers of stones containing the drainpipes

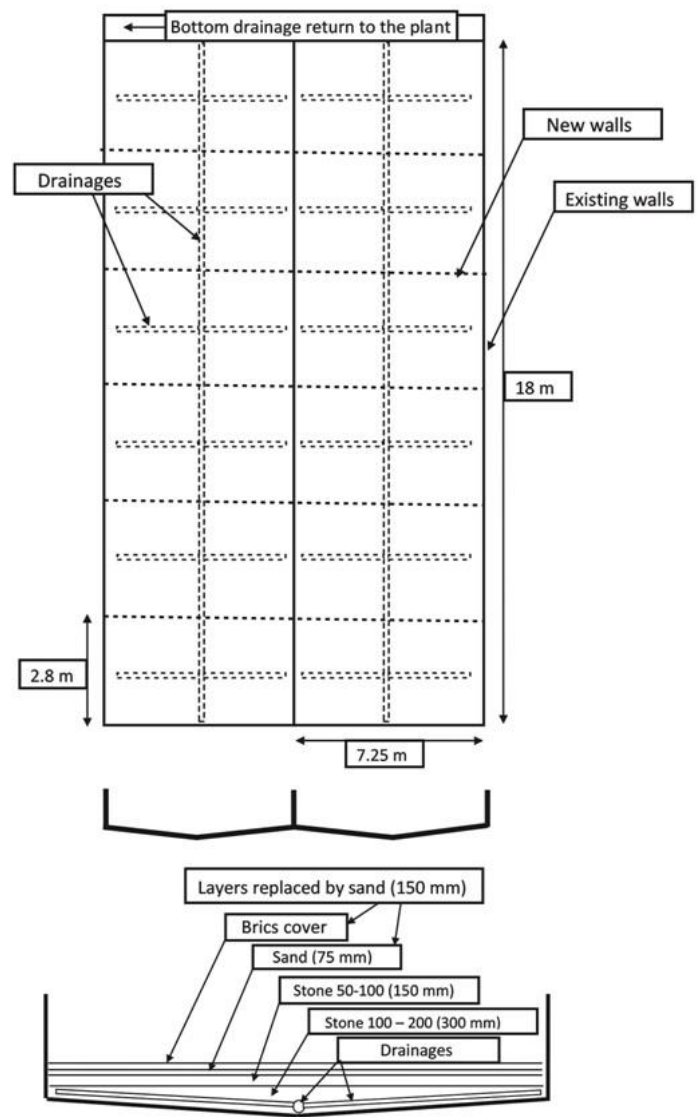

Source: Own source. 
Vegetation. As the INP authorities did not authorize the introduction of the common reed Phragmites australis (Cav.) Trin. ex Steud., the most frequently used plant $(3,10)$; the system was planted with species of the genus Hymenachne P. Beauv. $(H$. donacifolia [Raddi] Chase and H. pernambucense [Spreng.] Zuloaga), collected in the park, from the banks of the Iguazú River.

Operation. The system started operating in March of 2013. Every day $25 \mathrm{~m}^{3}$ of mixed liquor (ML) are discarded (waste sludge) into a thickener and left to settle for one hour. Then a submerged pump transfers every day the concentrated sludge (applied sludge) to the next cell following the numerical order. When all the sludge has been transferred, the clarified supernatant, water with some remaining solids, is returned from the thickener to the aeration basin (returned solids).

\section{Sampling}

Sludge sampling. Every day a settling test was performed on a ML sample and recorded as the SV30 (mL/ $\left.\mathrm{L}^{-1}\right)$, the solids volume accumulated after a 30 -min settling in a $1 \mathrm{~L}$ cylinder. On 35 sampling dates, 6 to 10 each year randomly distributed during the operational period, the amount of total (TSS) and volatile (VSS) suspended solids in the waste sludge, were also determined. For each sample, the sludge volume index $\left(\mathrm{SVI}, \mathrm{mL} / \mathrm{g}^{-1}\right)$ was calculated as the SV30 divided by the ML TSS $\left(\mathrm{g} / \mathrm{L}^{-1}\right)$ after Metcalf \& Eddy [5]. This database was used to further estimate the concentrations of the waste-sludge solids per day, as the SV30 divided by the average SVI. In a complementary fashion, on eleven sampling dates, the applied sludge and the clarified supernatant water were sampled to determine the concentration of the returned solids.

Final residue sampling. After four years of operation, the odd-numbered cells, originally a bit shallower, were almost full. These 6 cells were inactivated and left to rest for 5 months in order to enable the dewatering and stabilization of the residue upper layers. Afterwards, three samples of the accumulated material $(60 \mathrm{~cm}$ depth) were taken from each cell through a center line, at both ends and, in the middle, with a 110-mm-diameter pipe used as a core sampler. The three samples from each cell were mixed to give the composite samples $\mathrm{C} 1$, C3, C5, C7, C9, and C11, from the correspondingly numbered cells. The reduction in volatile solids (VS) the specific oxygen-uptake rate (SOUR), and the Escherichia coli concentrations were measured in each composite sample. The Salmonella sp. and the viable-helminth-egg concentrations were measured on three samples composed of $\mathrm{C} 1+\mathrm{C} 3$, $\mathrm{C} 5+\mathrm{C} 7$, and $\mathrm{C} 9+\mathrm{C} 11$ (i.e., 3 combined samples). For the heavy-metal-concentration analyses, the samples were grouped into $\mathrm{C} 1+\mathrm{C} 3+\mathrm{C} 11$ and $\mathrm{C} 5+\mathrm{C} 7+\mathrm{C} 9$ (i.e., 2 combined samples). 


\section{Analysis of Samples}

The TSS of the waste sludge and applied sludge were determined on samples filtered through weighed standard glass-fiber filters and dried to constant weight at $105{ }^{\circ} \mathrm{C}$ (APHA, $2540 \mathrm{D} ; 6)$. The VSS were calculated as the weight lost from the same filters after ignition at $550{ }^{\circ} \mathrm{C}$ (APHA $2540 \mathrm{E}$; 6). Total solids (TS) and volatile solids (VS) of the residues in the cells were determined by the same methods that were applied to residue samples (APHA $2540 \mathrm{G} ;$ 6). To evaluate the vector-attraction potential, VS reduction was determined as the difference between the VS concentration in the sludge applied to the cells and that in the residue of the cell and Specific Oxygen Uptake Rate (SOUR) was determined by dilution of a weighed quantity of residue sample containing $1.5 \mathrm{~g}$ TS in a convenient volume of distilled water, mechanical aeration, and measurement of the oxygenuptake rate with a YSI 52 dissolved-oxygen meter equipped with a YSI 5905 BOD Probe electrode (APHA, 2710 B) [6]. Heavy-metal concentrations were determined according to the EPA SW 846 [7] standard procedures by the following methods: As (M 7061A-EAA, hydride generation), $\mathrm{Hg}$ (7470A EAA, cold steam), Cd (M 7130-EAA ), Zn (M 7950 EAA), Cu (M 7210 EAA), Cr (M 7190 EAA), Ni (M 7520 EAA), and Pb (M 7420 EAA). Escherichia coli counts in the sludge applied to the cells were made on the same samples that were taken for TSS measurements. The E. coli concentrations in the sludge and in the residues of the cell were determined by the miniaturized method most-probable-number (MPN) technique in microtiter plates (ISO 9308-3) [8], while the presence of Salmonella sp. was assayed by enrichment in selenite-cystine broth at $35{ }^{\circ} \mathrm{C}$ and extended in xyloselysine-deoxycholate agar (APHA, 9260 B) [6]. Viable-helminth-egg concentrations were determined by the decant-and-centrifuge technique after Shurtleff and Averre [9].

Statistics. Averages and standard deviations of calculated SVI were used to estimate the concentrations of the waste-sludge solids, as the SV30 divided by the average SVI. The results obtained from VS reduction, SOUR, and E. coli concentration in each cell were used to calculate the coefficient of variation along with the standard deviation, expressed as a percentage of the average value, in order to compare the performance and variability between cells. Statistical analyzes were performed with the free InfoStat software, version 2020 [10].

\section{Results and Discussion}

Waste Sludge. The table 1 summarizes the statistics obtained from the sampling of waste, applied and returned sludge, throughout the entire experimental period. 
Table 1. Solids content and SVI values

\begin{tabular}{ccc}
\hline Operational parameters & Average & SD \\
\hline $\begin{array}{c}\text { ML sludge-settling volume }\left(\mathrm{mL} / \mathrm{L}^{-1}\right)(\mathrm{n}= \\
\text { 35) }\end{array}$ & 454 & 156 \\
\hline Waste sludge TSS content $\left(\mathrm{g} / \mathrm{L}^{-1}\right)(\mathrm{n}=35)$ & 1.40 & 0.41 \\
\hline Waste sludge VSS content $\left(\mathrm{g} / \mathrm{L}^{-1}\right)(\mathrm{n}=35)$ & 1.06 & 0.30 \\
\hline Applied sludge TSS content $\left(\mathrm{g} / \mathrm{L}^{-1}\right)(\mathrm{n}=11)$ & 5.46 & 1.58 \\
\hline Applied sludge VSS content $\left(\mathrm{g} / \mathrm{L}^{-1}\right)(\mathrm{n}=11)$ & 4.60 & 1.36 \\
\hline Applied sludge \%VSS-TSS $(\mathrm{n}=11)$ & 84.1 & 1.13 \\
\hline Returned solids_TSS content $\left(\mathrm{g} / \mathrm{L}^{-1}\right)(\mathrm{n}=11)$ & 0.284 & 0.081 \\
\hline Sludge-volume index $(\mathrm{SVI})\left(\mathrm{mL} / \mathrm{g}^{-1}\right)(\mathrm{n}=$ & 367 & 91 \\
$35)$ & &
\end{tabular}

ML, mixed liquor; TSS/VSS, total/volatile suspended solids

Source: Authors' own creation

Sludge loading. Through the use of the calculations indicated above on the basis of the ML concentration and an estimated $15 \%$ return of TS with the clarified supernatant, the corresponding cell was loaded daily with $17-26 \mathrm{~kg}$ TS at an average of $21.6 \mathrm{~kg}$ TS per application. Accordingly, after 4 years of operation and 1465 applications - an average of 122 applications per cell- the system was loaded with a total of $2600 \mathrm{~kg} \mathrm{TS} \mathrm{cell}^{-1}$, giving a total loading of 32,000 kgTS in the whole system, or roughly $130 \mathrm{~kg} \mathrm{TS} \mathrm{m}^{-2}$, during those four years. These figures likewise represent an input of $32.5 \mathrm{~kg} \mathrm{TS} \mathrm{m}^{-2} \mathrm{y}^{-1}$. As mentioned above, during the first year of operation (commissioning), owing to different causes of solid losses, the estimated loading rate was $25 \mathrm{~kg} \mathrm{TS} \mathrm{m}^{-2} \mathrm{y}^{-1}$. That figure increased with time to reach a rate of $65 \mathrm{~kg} \mathrm{TS} \mathrm{m}^{-2} \mathrm{y}^{-1}$ in the period of highest concentration. Nevertheless, the average loading rate was far below the maximum of 50-60 kg TS $\mathrm{m}^{-2} \mathrm{y}^{-1}$ widely recommended in the literature [11].

Vegetation. Although Phragmites australis, a cosmopolitan species, is present in Argentina, that plant is not registered in the INP or in the Province of Misiones. The introduction of non-autochthonous species was not allowed by the INP authorities. Therefore, the first sowing of the cells was done with several plant species selected and collected on the banks of the Iguazú river within the park. Those that grew faster and more vigorous were from the genus Hymenachne, plant that colonized all the cells, developed luxurious growth, and never exhibited signs of deterioration. In the second growing season, differences in size were observed, which later became evident as different species within that genus - namely, $H$. donacifolia (Raddi) Chase and $H$. pernambucense (Spreng.) Zuloaga. 
Sludge dewatering. The average TS concentration of the residues within the cells amounted to $14.3 \%$ (13.2 to 16.3; SD 1.19). Table 2 compared to the TS contained in the sludge applied to the cells, the value indicated a shift from $0.55 \%$ to $14.3 \%$ amounting to a 26-fold increase in the concentration. These values, however, were modest compared to certain enrichments reported in the literature (18 to $26 \%$ by Uggetti et al. [12] and $20 \%$ by Nielsen [11]). The cells in the INP system were shallower $(0.70 \mathrm{~m})$ than the standard recommended by the technology $-1.8 \mathrm{~m}$ in Nielsen [13] — and could not be charged for periods of 4 to 5 successive days because of the volume limitations. The cells were utilized by loading a different one each day, thus attaining a resting time of 11 days between loadings. Nielsen [11] reported a typical final TS concentration of $20 \%$ in several Danish systems operated with 40 to 50 days of resting time between loadings, figures that could increase to up to $40 \%$ with resting times of 60 to 75 days. In all likelihood, our results would be improved if longer resting periods could be attained with bigger cells. Another consideration with respect to the dehydration rate obtained is that the INP system works under a rainfall regime of almost $2 \mathrm{~m} \mathrm{y}^{-1}$, amount of precipitation that represents a $25 \%$ extra volume of water to be evapotranspired in addition to the one added with the sludge. Nonetheless, the $14.3 \%$ TS concentration obtained indicated the ability of the system to remove enough water from the sludge to produce a sufficiently solid material for easy handling with a small mechanical shovel. An additional advantage in this approach was that the residues analyzed contained final concentrations of $21.9 \mathrm{~g}$ total nitrogen and $8.4 \mathrm{~g}$ of total phosphorus per $\mathrm{kg}$ of TS (data not shown), enrichment that underscored the value of this system as a source of nutrients for soil amendment.

Vector-attraction parameters. Annex II, in table 1 of National Resolution 410/18, requires that the residues comply with one of two vector-attraction parameters: VS reduction or SOUR. On the average, $56.1 \%$ of the TS concentrations represented VS. Compared to the composition of the applied sludge (at $84.1 \%$ VS in the TS), the average VS reduction was $33.3 \%$ (range 31.8 to $36.5 \%$; SD 2.05). In table 2 none of the samples, however, complied with the value required by National Resolution 410/18 (i.e., VS reduction by $>38 \%$ ). The Code of Federal Regulations [14] explains without specifics that the sludge coming from strong aerobic treatments are already partially or totally stabilized and thus cannot possibly reach that VS reduction level. That limitation seems to be the situation with the INP-activated-sludge treatment, system that operates with a 24-h hydraulic-residence time and 20 to 25 days of sludge age.

The SOUR exhibited an average value of $1.09 \mathrm{mg} \mathrm{O}_{2} \mathrm{~g} \mathrm{TS}^{-1} \mathrm{~h}^{-1}$ (range 0.8 to 1.31; SD 0.18; table 2). All the samples fulfilled the requirement demanded by National Resolution 410/18. (i.e., $\mathrm{SOUR}<1.5 \mathrm{mg} \mathrm{O}_{2} \mathrm{~g} \mathrm{TS}^{-1} \mathrm{~h}^{-1}$ ). 
Table 2. Vector-attraction-parameter compliance, residue water and TS content, VS reduction, and SOUR

\begin{tabular}{cccccc}
\hline $\begin{array}{c}\text { Parameter* } \\
\text { Units }\end{array}$ & $\mathbf{\%} \mathbf{H}_{2} \mathbf{O}$ & $\%$ TS & \%VS in TS & \%VS red & SOUR \\
\hline Sludge average & $\mathbf{9 9 . 4 5}$ & $\mathbf{0 . 5 5}$ & $\mathbf{8 4 . 1}$ & & \\
\hline Sample & & & & & \\
\hline C1 & 83.7 & 16.3 & 53.4 & 36.5 & 0.80 \\
\hline C 3 & 85.9 & 14.1 & 57.3 & 31.8 & 1.11 \\
\hline C5 & 85.1 & 14.9 & 56.0 & 33.4 & 1.07 \\
\hline C7 & 86.8 & 13.2 & 56.7 & 32.6 & 1.22 \\
\hline C9 & 86.7 & 13.3 & 58.1 & 30.9 & 1.00 \\
\hline C11 & 86.1 & 13.9 & 54.9 & 34.7 & 1.31 \\
\hline Residue average & $\mathbf{8 5 . 7}$ & $\mathbf{1 4 . 3}$ & $\mathbf{5 6 . 1}$ & $\mathbf{3 3 . 3}$ & $\mathbf{1 . 0 9}$ \\
\hline SD & $\mathbf{1 . 1 9}$ & $\mathbf{1 . 1 9}$ & $\mathbf{1 . 7 2}$ & $\mathbf{2 . 0 5}$ & $\mathbf{0 . 1 8}$
\end{tabular}

*TS, total solids; VS, volatile solids; SOUR, specific oxygen-uptake rate

Source: Own source.

Heavy metals. The average heavy-metal concentrations —expressed in $\mathrm{mg} \mathrm{kg} \mathrm{TS}^{-1}$ were: As, 2.9 (limiting value [L.V.] 75); Cd, 0.4 (L.V., 40); Zn, 919.6 (L.V., 4,000); Cu, 270.8 (L.V., 1750); Total Cr, 25.8 (L.V., 1500); Hg, 1.0 (L.V., 25) Ni, 27.3 (L.V., 400); and $\mathrm{Pb}, 82.2$ (L.V., 1200). In table 3 the heavy-metal concentrations were far below the maximum levels required by National Resolution 410/18. The most concentrated species ( $\mathrm{Zn}$ and $\mathrm{Cu}$ ) reached only $23 \%$ and $15.5 \%$, respectively, of those maxima, with all the rest below $10 \%$. This result was expected since the treated wastewater comes exclusively from sanitary and food services. The low metal concentrations determined also enabled the application of the treated materials to soils at a large margin below the annual maximum load of pollutants (e.g., 30 and $12 \mathrm{Kg} \mathrm{Ha}^{-1} \mathrm{y}^{-1}$, for $\mathrm{Zn}$ and $\mathrm{Cu}$, respectively, according to annex II, table 6 of the Resolution). 
Table 3. Residue heavy-metal content

\begin{tabular}{|c|c|c|c|c|c|}
\hline Limiting values & Metal & $\begin{array}{c}\mathrm{C} 1+\mathrm{C3}+ \\
\mathrm{C} 11\end{array}$ & $\mathrm{C} 5+\mathrm{C} 7+\mathrm{C} 9$ & $\begin{array}{c}\text { Cells } \\
\text { average }\end{array}$ & $\begin{array}{c}\text { Max } \\
\text { Acceptable }\end{array}$ \\
\hline $\mathrm{mg} \mathrm{kg} \mathrm{TS}^{-1}$ & & $\mathrm{mg} \mathrm{kg} \mathrm{TS}^{-1}$ & $\mathrm{mg} \mathrm{kg} \mathrm{TS}$ & & \\
\hline 75 & As & 3.1 & 2.6 & 2.9 & 3.80 \\
\hline 40 & $\mathrm{Cd}$ & 0.4 & 0.5 & 0.4 & 1.04 \\
\hline 4000 & $\mathrm{Zn}$ & 836.3 & 1002.8 & 919.6 & 22.99 \\
\hline 1750 & $\mathrm{Cu}$ & 247.0 & 294.5 & 270.8 & 15.47 \\
\hline 1500 & $\mathrm{Cr}$ & 24.6 & 26.9 & 25.8 & 1.72 \\
\hline 25 & $\mathrm{Hg}$ & 1.0 & 1.0 & 1.0 & 4.00 \\
\hline 400 & $\mathrm{Ni}$ & 26.8 & 27.8 & 27.3 & 6.83 \\
\hline 1200 & $\mathrm{~Pb}$ & 80.8 & 83.5 & 82.2 & 6.85 \\
\hline
\end{tabular}

Pathogens concentrations. The average counts of E. coli were $102 \mathrm{MPN} \mathrm{g} \mathrm{TS}^{-1}$ (range 46.6 to $231.1 \mathrm{MPN}_{\mathrm{g} \mathrm{TS}}{ }^{-1}$ ) Salmonella sp. and viable Helminth eggs were absent in $4 \mathrm{~g}$ TS. All the samples fulfilled the values demanded by the National Resolution 410/18 for classification as Level-A biosolids (table 4).

Table 4. Residue-pathogen content and classification according to Nat. Res. 410/18

\begin{tabular}{|c|c|c|c|c|}
\hline Parameter & Escherichia coli & Salmonella sp. & Viable helminth eggs* & \\
\hline & Required value & Required value & Required value & \\
\hline & Level A & Level A & Level A & \\
\hline \multirow[t]{2}{*}{ Cell } & $<10^{3} \mathrm{MPN} \mathrm{g} \mathrm{TS}^{-1}$ & $<3 \mathrm{MPN} 4 \mathrm{~g} \mathrm{TS}^{-1}$ & $<14 \mathrm{~g} \mathrm{TS}^{-1}$ & \\
\hline & Result & Result & Result & Class \\
\hline $\mathrm{C} 1$ & 57.3 & $\mathrm{C} 1+\mathrm{C} 3$ & $\mathrm{C} 1+\mathrm{C} 3$ & $\mathbf{A}$ \\
\hline $\mathrm{C} 3$ & 46.6 & Absent & Absent & $\mathbf{A}$ \\
\hline $\mathrm{C} 5$ & 89.6 & $\mathrm{C} 5+\mathrm{C} 7$ & $\mathrm{C} 5+\mathrm{C} 7$ & $\mathbf{A}$ \\
\hline C7 & 119.9 & Absent & Absent & $\mathbf{A}$ \\
\hline C9 & 67.3 & $\mathrm{C} 9+\mathrm{C} 11$ & $\mathrm{C} 9+\mathrm{C} 11$ & $\mathbf{A}$ \\
\hline C11 & 231.1 & Absent & Absent & $\mathbf{A}$ \\
\hline Average & 102.0 & & & \\
\hline SD & 68 & & & \\
\hline $\mathrm{CV}^{*}$ & 13 & & & \\
\hline
\end{tabular}

The E. coli counts in the concentrated sludge applied to the cells ranged between $5 \times 10^{6}$ and $2 \times 10^{7} \mathrm{MPN} \mathrm{L}^{-1}$ (at an average of $1 \times 10^{7} \mathrm{MPN} \mathrm{L}^{-1}$ ). As indicated above, the average 


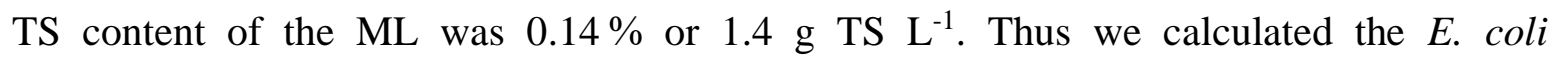
concentration in the input sludge to the cells to be $1 \times 10^{7} \mathrm{MPN} \mathrm{L}^{-1}$ divided by $1.4 \mathrm{~g} \mathrm{TS} \mathrm{L}^{-1}$ or $7.1 \times 10^{6} \mathrm{MPN} g \mathrm{TS}^{-1}$. The average $E$. coli concentration in the analyzed residues was $1.0 \times 10^{2}$ MPN g TS${ }^{-1}$, figure that represents a reduction in bacterial ( $E$. coli) concentration above 4 logs. Nielsen [13] reported a final concentration of less than $2 \times 10^{2}$ in the whole column of sediment beds in Helsinge, Denmark, after 3 months without loadings, while Uggetti [12] reported < 3 MPN g TS ${ }^{-11}$ of $E$ coli in the sediments of Seva, after 4 months of resting. Our final concentration $-4.7 \times 10^{1}$ to $2.3 \times 10^{2} \mathrm{MPN}_{\mathrm{g}} \mathrm{TS}^{-11}$ - represents between 5 and $23 \%$ of the maximum value accepted by the National Resolution $410 / 18$ of $<10^{3}$ MPN $\mathrm{g} \mathrm{TS}^{-1}$. These values and the absence of pathogens enable a classification of the processed sludges as Class-A biosolids, without use restrictions. According to title IV, art. 10, involving the forms of use and final disposal, these residues could be used for forestation and floriculture, the recovery of degraded sites, the restoration of landscapes and general landscaping, the development of fertilizers or amendments, the closure of sanitary fillers, and/or the development of construction materials.

The analysis performed on every individual cell residue revealed quite homogeneous results with precision well below $20 \%$. Within the vector-attraction parameters (table 2), the VS reduction indicated a coefficient of variation $(\mathrm{CV})$ of $6.14 \%$ and the SOUR a CV of $16.4 \%$; while the $E$. coli counts, after $\log _{10}$ transformation for normal distribution analysis, evidenced a CV of $13 \%$ (table 4 ).

\section{Conclusions}

The experimental project carried out at the Iguazú National Park, Misiones, Argentina, demonstrated that the sludge treatment reed beds technology was successful in:

(i) Reaching a dewatering (concentration) of waste sludges from 0.4 to $14 \% \mathrm{TS}$

(ii) Generating a well stabilized (low vector-attraction-potential) sludge,

(iii) Generating a sanitary, safe sludge — at $<10^{3}$ E. coli NMP g TS ${ }^{-1}$,

(iv) Generating a sludge enriched in $\mathrm{N}$ and $\mathrm{P}$ - at $21.9 \mathrm{~g}$ total nitrogen and $8.4 \mathrm{~g}$ total phosphorus per $\mathrm{kg}$ of TS,

(v) Generating a Class-A-biosolids residue that, according to National Resolution 410/18 and to the Code of Federal Regulations, is reusable for agronomic and landscape purposes.

These results were obtained in a tropical climate of average annual temperature of 17 to 27 ${ }^{\circ} \mathrm{C}$ and a rainfall of $1870 \mathrm{~mm} \mathrm{y}^{-1}$ and with the locally available vegetation cover Hymenachne donacifolia (Raddi) Chase and H. pernambucense (Spreng.) Zuloaga, quite 
different from most of the systems referenced in the literature, with those being carried out in temperate or cold climates. The present results suggest that the sludge treatment-reed beds technology is extremely versatile and with facile application to a wide range of climatic and biogeographic conditions. Moreover, the sludge treatment in the reed beds system produced other sanitary and economic benefits. Dry solids do not have to be shoveled and bagged, thus saving man hours and a sanitary risk for workers, and moreover they do not need to be transported to a safety landfill or disposed of in any manner. Finally, with this technology, the residue volume was significantly reduced by dehydration; and, at almost no energy cost, the wasted sludge stabilized and became $221 \mathrm{t}$ (in $144 \mathrm{~m}^{3}$ ) of a harmless product whose reduction in weight and bulk enabled the safe disposal and reuse in soil amendment.

\section{Acknowledgment}

The authors wish to express our appreciation to Ing. Marcelo Zuliani, manager of Iguazú Argentina SA, Mr. Ricardo Hilbert, and park ranger Dalma Raymundi of APN, NEA, for their permanent collaboration and interest.

\section{References}

[1] S. Nielsen and E. W. Bruun, "Sludge quality after 10-20 years of treatment in reed bed systems," Environ. Sci. Pollut. Res., vol. 22, pp. 12885-12891, 2015. Available: https://doi.org/10.1007/s11356-014-3815-6

[2] I. Kengne and E. Tilley, "Drying beds with plants," in Fecal Sludge Management. A Systemic Approach for its Implementation and Operation, L. Strande, M. Ronteltap, and D. Brdjanovic, Eds. First Ed. London: IWA, 2014.

[3] E. Uggetti, I. Ferrer, E. Llorens, and J. Garcia, "Sludge treatment wetlands: A review on the state of the art," $R$. Bioresource Technol., vol. 101, no. 9, pp. 2905-2912, 2010. Available: https://doi.org/10.1016/j.biortech.2009.11.102

[4] Ministerio de Ambiente y Desarrollo Sustentable, Rep. Argentina. (2018, Jul. 12). Resolución 410/18. Manejo sustentable de barros y biosólidos generados en plantas depuradoras de efluentes líquidos cloacales y mixtos cloacales-industriales. Available: http://argentinambiental.com/legislacion/nacional/resolucion-41018-manejo-sustentable-barrosbiosolidos-generados-plantas-depuradoras-efluentes-liquidos-cloacales-mixtos-cloacalesindustriales/

[5] Metcalf \& Eddy. Ingeniería sanitaria. Tratamiento, evacuación y reutilización de aguas residuales. 3rd ed. Colombia: Quinto Centenario, 1994.

[6] American Water Works Association, American Public Health Association, and Water Environment Federation, Standard Methods for the Examination of Water and Wastewater. 20th ed. Washington, D. C.: APHA-AWWA-WEF, 1998.

[7] United States Environmental Protection Agency, The SW-846 Compendium. Available: https://www.epa.gov/hw-sw846/sw-846-compendium 
[8] Water quality: Detection and enumeration of Escherichia coli and coliform bacteria. Part 3: Miniaturized method (Most Probable Number) for the detection and enumeration of E. coli in surface and waste water, ISO 9308-3, 1998. Available: https://www.iso.org/standard/20878.html

[9] M. Shurtleff and C. Averre, "Diagnosing Plant Diseases Caused by Nematodes," J. Agric. S., vol. 138, no, 03, pp. 345-348, 2000.

[10] J. A. di Rienzo, F. Casanoves, M. G. Balzarini, L. Gonzalez, M. Tablada, and C. W. Robledo. (2020). InfoStat. [Online]. Available: http://www.infostat.com.ar

[11] S. Nielsen, "Sludge reed bed facilities: Operation and problems," Water S. Technol., vol. 51, no. 9, pp., 99-107, 2005. Available: https://doi.org/10.2166/wst.2005.0297

[12] E. Uggetti, I. Ferrer, S. Nielsen, C. Arias, H. Brix and J. García, "Characteristics of biosolids from sludge treatment wetlands for agricultural reuse,” Ecol. Eng., vol. 40, pp. 210-216, 2012. Available: https://doi.org/10.1016/j.ecoleng.2011.12.030

[13] S. Nielsen, "Helsinge sludge reed bed system: Reduction of pathogenic microorganisms," Water S. Techn., vol. 56, no 3, pp. 175-182, 2007. Available: https://doi.org/10.2166/wst.2007.491

[14] 40 CFR 503.30. Code of Federal Regulations, title 40, part 503, subpart D. Revised July, 1998. US GPO. Available: https://www.govinfo.gov/app/details/CFR-2010-title40-vol29/CFR-2010-title40vol29-sec503-30 